\title{
Effect of aged garlic powder on physicochemical characteristics, texture profiles, and oxidative stability of ready-to-eat pork patties
}

\author{
Ji-Han Kim ${ }^{1,2}$, Hyun-Joo Jang ${ }^{2}$, and Chi-Ho Lee ${ }^{2, *}$
}

\footnotetext{
* Corresponding Author: Chi-Ho Lee Tel: +82-2-450-3681, Fax: +82-2-450-1948, E-mail: leech@konkuk.ac.kr

${ }^{1}$ Department of Food and Bioproduct Sciences, University of Saskatchewan, Saskatoon, SK, S7N5A8, Canada

${ }^{2}$ Department of Food Science \& Biotechnology of Animal Resources, Konkuk University, Seoul 05029, Korea
}

ORCID

Ji-Han Kim

https://orcid.org/0000-0001-8197-0612

Hyun-Joo Jang

https://orcid.org/0000-0002-4186-883X

Chi-Ho Lee

https://orcid.org/0000-0001-9406-8310

Submitted Sept 10, 2018; Revised Nov 5, 2018; Accepted Dec 8, 2018
Objective: The aim of this study was to investigate the effects of aged garlic powder (AGP) on physicochemical characteristics, texture profiles, and oxidative stability of ready-to-eat (RTE) pork patties.

Methods: There were five treatment groups: a control; $1 \%$ fresh garlic powder (T1); $0.5 \%$, $1 \%$, and $2 \% \mathrm{AGP}\left(\mathrm{T} 2, \mathrm{~T} 3\right.$, and T4). Pork patties with vacuum packaging were roasted at $71^{\circ} \mathrm{C}$ for core temperature, stored at $4^{\circ} \mathrm{C}$ for $14 \mathrm{~d}$, and then reheated for $1 \mathrm{~min}$ using a microwave. Results: The AGP groups showed a lower the level of lipid oxidation and higher thiol contents than the control and $\mathrm{T} 1$. The $\mathrm{pH}$ value of the control increased whereas that of aged garlic groups decreased after re-heating process. In addition, the redness significantly increased with increasing level of AGP whereas the redness of the control and T1 decreased after reheating process. T4 added patties improved textural and sensory properties compared to the control.

Conclusion: The results of this study suggest that AGP addition to RTE pork patties can improve their sensory characteristics and oxidative stability.

Keywords: Aged Garlic; Patties; Thiol; Ready-to-eat; Lipid Oxidation

\section{INTRODUCTION}

In recent years, garlics have been used as a main ingredient for meat product. Garlics provide plentiful phenol compounds and sulfur-containing compounds such as cysteine, alliin, and allyl disulfide to improve flavor and extent shelf-life of meat products [1-3]. In addition, heating process on garlic significantly improves taste-active compounds, which are related to strong mouthfullness (kokumi taste), through Maillard reaction [4]. The Maillard reaction between amino acids and glucose contributes to the occurrence of non-enzymatic browning reaction that develops color and flavor intensity during cooking [3].

Aged garlic (AG) is well-known as black garlic which is processed by heat $\left(50^{\circ} \mathrm{C}\right.$ to $\left.90^{\circ} \mathrm{C}\right)$ and time (more than one month) treatments [5]. Antioxidant ability of AG is increased compared to fresh garlic (FG) since S-allyl cysteine of AG is increased with Maillard reaction during such processing [6]. In terms of human/animal diet, functionalities such as antiallergic and antioxidant activities of $A G$ have been determined in previous studies $[7,8]$. Recently, the application of AG in foods such as sausage [9] and sponge cake [10] has been studied, revealing that AG can extend shelf life of foods.

Recently, consumers prefer to eat food with more convenience, resulting in the growth of ready-to eat (RTE) food market [11]. Many studies have been performed to inhibit lipid and protein oxidation of RTE products [12-14]. Liberation of heme iron from myoglobin 
during cooking and reheating accelerates oxidation of RTE meat [15]. Meat deterioration is mainly derived from lipid and protein oxidation with formation of volatile compounds responsible for off-flavors and rancid odor [16].

Based on these reports, we hypothesized that the addition of AG to ready to eat pork patties could positively influence their sensory characteristics and oxidative stability. Therefore, the aim of this study was to investigate the effect of AG on quality and oxidative stability of RTE pork patties.

\section{MATERIALS AND METHODS}

\section{Preparation of sample and pork patties}

The FG and AG powders were obtained from OZL DNF Inc. (Dam Yang, Korea). Garlic samples (FG and AG) were freezedried for powdering process. Fresh pork hams (lean meat) and back fat were obtained from GUMDON Corp. (Won Ju, Korea). Pork patties ( $65 \mathrm{~g}$ ) were processed by finger kneading at once using patty-maker (small round burger press, Spikomat Ltd., UK) into approximately $100 \mathrm{~mm}$ diameter and $10 \mathrm{~mm}$ thickness with the basic formulations given in lean meat $785 \mathrm{~g} / \mathrm{kg}$, back fat $200 \mathrm{~g} / \mathrm{kg}$ and sodium chloride $15 \mathrm{~g} / \mathrm{kg}$ (Control group, without garlic powder; T1, 1\% FG powder; T2, T3, and T4, $0.5 \%, 1 \%$, and $2 \%$, respectively). Each of the five treatments was performed with three different manufacturing processes as follows (Figure 1): i) For fresh patties, color, $\mathrm{pH}$, and proximate compositions of raw patties were measured immediately after production; ii) the pork patties were grilled in open electric griddles (Preheated temperature $260^{\circ} \mathrm{C} \pm 5^{\circ} \mathrm{C}$, HANSOL Inc., Seoul, Korea). Patties were cooked on the first side for $1 \mathrm{~min}$, the second side for $1 \mathrm{~min}$, and then each side turned for a final $2 \mathrm{~min}$ for a total of 6 min according to the method of Berry and Bigner-George [17]; iii) For reheated patties (RTE), pre-cooked patties were refrigerated at $4^{\circ} \mathrm{C}$ for $14 \mathrm{~d}$ in a polyethylene/nylon vacuum bags (Cryovac, Duncan, SC, USA). They were then cooked with a microwave. The microwave oven (RE-338BR, Samsung Electronics Co., Ltd., Suwon, Korea) was pre-set to 500 $\mathrm{mW}$ for $1 \mathrm{~min}$. After cooking, patties were allowed cool off at room temperature for experimentation. All experiments were performed in triplicates.

\section{Proximate compositions analysis}

Proximate compositions (moisture, crude protein, crude fat, and ash) were analyzed using methods of the Association of Official Analytical Chemists [18].

\section{Color measurement}

Color of samples was measured using a colorimeter (CR-400, Konica Minolta Sensing, Inc., Osaka, Japan). The colorimeter was calibrated with standard (Commission Internationale de l'Eclairage [CIE], $\mathrm{L}^{*}=+97.43, \mathrm{CIE} \mathrm{a}^{*}=-0.05, \mathrm{CIE}^{*}=+1.92$ ). CIE L*-value (lightness), CIE $\mathrm{a}^{*}$-value (redness), and CIE $\mathrm{b}^{*}$-value (yellowness) were determined for the surface of each

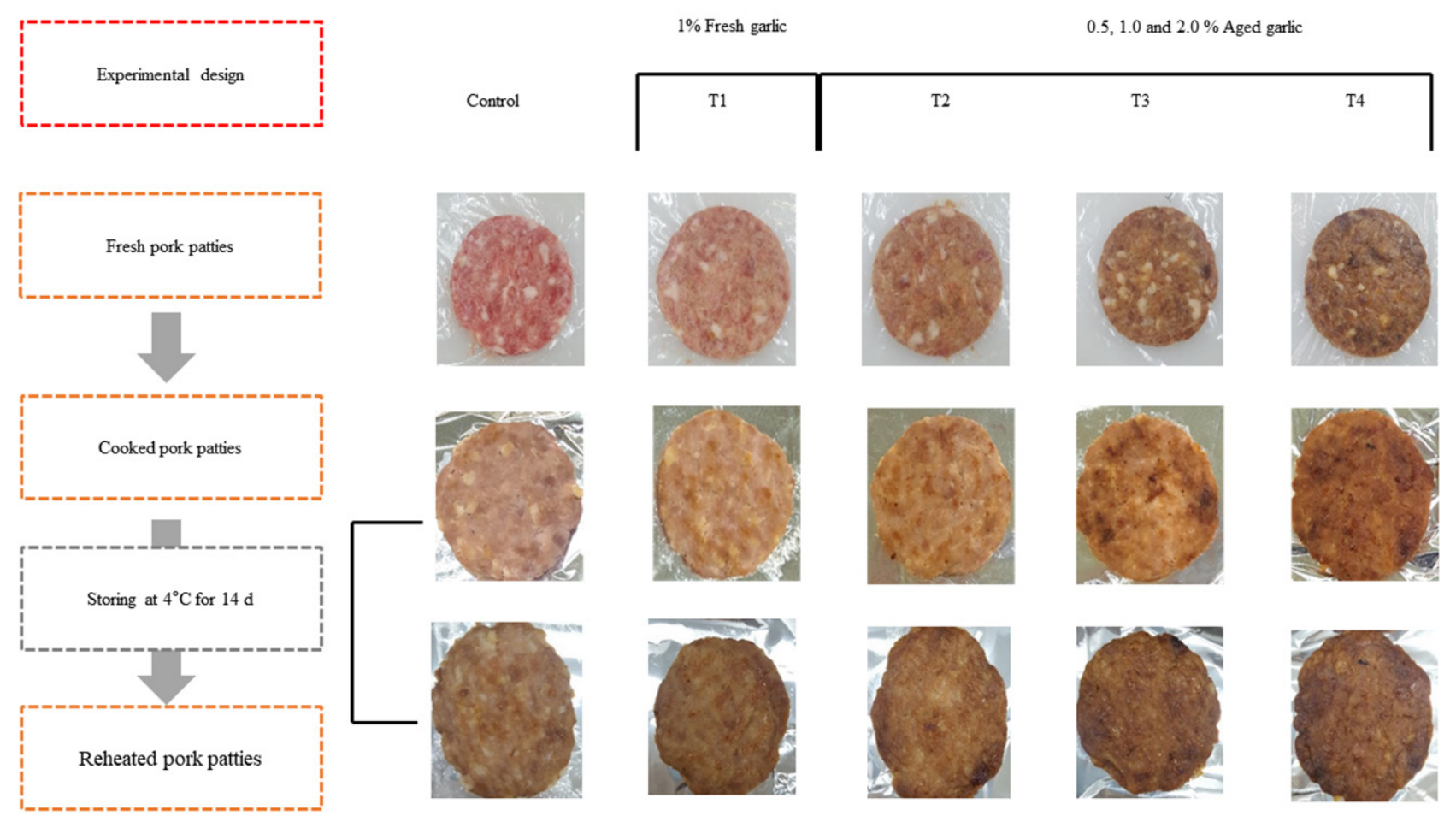

Figure 1. Schematic figure showing experimental design of this study. Control, pork patties without fresh or aged garlic powder; $\mathrm{T} 1,1 \%$ fresh garlic (w/w), $\mathrm{T} 2, \mathrm{~T} 3$, and T4, $0.5 \%, 1 \%$, and $2 \%$ aged garlic (w/w). 
sample.

Browning intensity of Maillard reaction products Brown intensity (BI) of Maillard reaction products (MRPs) was determined for cooked and reheated pork patties by the method of Smith and Alfawaz [19]. Briefly, $2 \mathrm{~g}$ of sample was homogenized with $18 \mathrm{~mL}$ of distilled water and then filtered through Whatman paper No. 1. The BI of sample was measured at wavelength of $420 \mathrm{~nm}$ using a spectrophotometer (Libra S22, Biochrom, Cambridge, England). The BI difference was calculated as follows: the ratio of cooked sample to fresh sample $(\Delta \mathrm{C})$ and the ratio of reheated sample to fresh sample $(\Delta \mathrm{R})$.

\section{$\mathrm{pH}$ measurement}

The $\mathrm{pH}$ value of sample was measured with a digital $\mathrm{pH}$-meter (LAQUA F-71, HORIBA, Kyoto, Japan). Briefly, $2 \mathrm{~g}$ of sample and $18 \mathrm{~mL}$ of distilled water were added into a bag filter. The sample was blended using a Bag Mixer (400 P, Interscience Co, Saint Nom, France) for $90 \mathrm{~s}$ followed by $\mathrm{pH}$ measurement.

\section{Cooking loss}

After cooking, patties were cooled at room temperature. Cooking loss was computed using the following equation:

Cooking loss (\%)

$=\frac{[\text { Weight of patty before cooking }(\mathrm{g})-\text { Weight of patty after cooking }(\mathrm{g})]}{\text { Weight of patty before cooking }(\mathrm{g})} \times 100$

\section{2-Thiobarbituric acid reactive substances}

Lipid oxidation was determined in triplicates using 2-Thiobarbituric acid reactive substances (TBARS) method of Tarladgis et al [20] with slight modifications. Briefly, $5 \mathrm{~g}$ sample was homogenized with $25 \mathrm{~mL}$ distilled water for $1 \mathrm{~min}$ at 10,000 $\mathrm{rpm}$. The mixture was then transferred to a distillation flask. The tube used for mixing was washed with an additional 23.5 $\mathrm{mL}$ of distilled water. To the same distillation flask, $4 \mathrm{~N} \mathrm{HCl}$ $(1.25 \mathrm{~mL})$ with antifoam agent $(1 \mathrm{~mL})$ a few boiling stones were added to prevent puffing. The mixture was heated to obtain distillate. Heating was stopped when $30 \mathrm{~mL}$ of distillate was collected in the other tube. To each $5 \mathrm{~mL}$ of collected distillate, $5 \mathrm{~mL}$ of TBA reagent $(0.002 \mathrm{M}$ 2-thiobarbituric acid in $90 \%$ acetate) was added and well-mixed. The mixture was then heated in water bath at $100^{\circ} \mathrm{C}$ for $30 \mathrm{~min}$ to develop chromogen followed by cooling in a refrigerator. Absorbances were measured at wavelength of $538 \mathrm{~nm}$ on a UV/vis spectrophotometer (Libra S22, Biochrom, England) and calculated as mg malondialdehyde (MDA)/kg meat using 1,1,3,3-tetraethoxypropane to prepare a standard curve.

\section{Determination of sulfhydryl groups}

Total sulfhydryl (thiol) content was quantified spectrophoto- metrically after derivatization by Ellman's reagent 5,5'-Dithiobis (2-nitrobenzoic acid) (DTNB) as described by Jongberg et al [21]. Briefly, $1 \mathrm{~g}$ of patty sample was homogenized in $20 \mathrm{~mL}$ of $5 \%$ sodium dodecyl sulfate (SDS) buffer for $30 \mathrm{~s}$. Homogenized sample was placed in a water bath at $80^{\circ} \mathrm{C}$ for $1 \mathrm{~h}$ followed by cooling. The solution was filtered through a Whatman filter paper (No. 1, Whatman Inc., Puscataway, NJ, USA) and then diluted 5-fold. Total sulfhydryl contents in 5-fold diluted supernatant was analyzed. After adding $2 \mathrm{~mL}$ of $0.1 \mathrm{M}$ Tris buffer (pH 8.0) and $0.5 \mathrm{~mL}$ of $10 \mathrm{mM}$ DTNB in $0.1 \mathrm{M}$ Tris buffer (pH 8.0) to $0.5 \mathrm{~mL}$ sample, the mixture was shielded from light and allowed to react for $30 \mathrm{~min}$. Absorbance was then measured spectrophotometrically at $412 \mathrm{~nm}$. A solution containing $0.5 \mathrm{~mL}$ of $5 \%$ SDS in Tris buffer (pH 8.0), $0.5 \mathrm{~mL}$ of $10 \mathrm{mM}$ DTNB, and $2.0 \mathrm{~mL}$ of $0.1 \mathrm{M}$ Tris buffer $(\mathrm{pH} 8.0$ ) was used as reagent blank. Protein content was determined using a standard curve of bovine serum albumin at wavelength of $550 \mathrm{~nm}$ through biuret reaction. Sulfhydryl content was computed using the following equations:

$$
\begin{aligned}
\text { i) } \begin{aligned}
\text { Molecular extinction coefficient } & =\mathrm{E} 412 \\
& =14,000 \mathrm{M}^{-1} \mathrm{~cm}^{-1}
\end{aligned} \\
\text { Thiol concentration }(\mathrm{nM})=\mathrm{OD} \times \mathrm{DF} / 0.014 \mathrm{nM}^{-1} \mathrm{~cm}^{-1}
\end{aligned}
$$

ii) Thiol $\mathrm{nM} / \mathrm{mg}=$ Thiol concentration $(\mathrm{nM})$ /protein concentration (mg)

\section{Texture profile analysis}

Texture profile analysis (TPA) of patties was carried out in triplicates for each treatment using a Texture Analyzer (CT31000, Brookfield Engineering Laboratories, Inc., Middelbro, MA, USA). Six samples were cut approximately $25 \mathrm{~mm} \times 10$ $\mathrm{mm}$ (diameter $\times$ height) from central section of each patty treatment. Before analysis, samples were allowed to equilibrate at room temperature for $30 \mathrm{~min}$. The setting was: distance $=$ $6.0 \mathrm{~mm}$, pre-test speed $=2.0 \mathrm{~mm} / \mathrm{s}$, post-test speed $=8.0 \mathrm{~mm} / \mathrm{s}$, head speed $=2.0 \mathrm{~mm} / \mathrm{s}$, and force $=5.0 \mathrm{~g}$. Patties of TPA values for springiness, gumminess ( $\mathrm{kg}$ ), cohesiveness, hardness (kg), and chewiness $(\mathrm{kg})$ were determined using methods describe by Bourne [22].

\section{Sensory evaluation}

Sensory evaluation was conducted at Konkuk University, Republic of Korea. Panels were made up of ten members who have experience in meat product sensory evaluation (graduates and faculty, both sexes and age of 23 to 55 years, Konkuk University, Department of Food Science and Biotechnology of Animal Resources). The panels were selected through three preliminary tests to recognize differences among the groups. Cooked patties were refrigerated overnight and allowed to stand at room temperature for $30 \mathrm{~min}$ before evaluation. Each sample slice $(10 \times 10 \times 10 \mathrm{~mm})$ was served to each panelist, ran- 
domly. The panels were asked to evaluate the quality of samples at a day in duplicate (morning and afternoon). Cooked patties were evaluated for flavor $(1=$ undesirable to $7=$ desirable $)$, taste $(1=$ undesirable to $7=$ desirable $)$, texture $(1=$ tough to $7=$ tender), juiciness $(1=$ dry to $7=$ juicy $)$, and overall preference ( $1=$ undesirable to $7=$ desirable) using a seven-point hedonic scale.

\section{Statistical analysis}

A randomized block experiment design with five treatments (Control, T1, T2, T3, and T4) and post-treatment (cooked and reheated) was used in triplicate. Effect of AG powder and processing application on each measured parameter was analyzed by two-way analyses of variance using IBM SPSS statistics 24.0. Post-treatment exclusively included fresh patties, cooked, and reheated samples in analysis of color and MRPs. Data are presented as mean \pm standard error of means. Significant differences between different treatments were analyzed using Tukey test. A p-value of less than 0.05 was considered statistically significant.

\section{RESULTS AND DISCUSSION}

\section{Physicochemical properties}

Proximate composition (moisture, crude protein, crude fat, and ash) of raw patties among the control, T1, T2, T3, and $\mathrm{T} 4$ did not show significant differences among groups (proximate composition data of raw patties not shown). As shown in Table 1, moisture (46.49\% to $48.06 \%$ ) of RTE pork patties was not affected by the addition of FG/AG powder. Moisture content was decreased from $50.66 \%$ to $43.73 \%$ by reheating regardless of the addition of FG/AG powder since the moisture content in samples was dehydrated during the heat process.

A decreasing tendency of $\mathrm{pH}$ was detected with increasing AGP concentration $(\mathrm{p}<0.001$, Table 1$)$ and the $\mathrm{pH}$ of $\mathrm{T} 1$ was significantly higher than that of the control group. Similar to our results, Shin et al [9], found that $\mathrm{pH}$ of AG added sausages decreased during storage. Pre- and post-treatment interaction effect of $\mathrm{pH}$ was proved $(\mathrm{p}<0.001)$ since $\mathrm{pH}$ was increased from 6.37 to 6.41 in the control group but decreased in T2 (6.38 to 6.26), T3 (6.28 to 6.17), and T4 (6.21 to 5.96). It has been reported that the heating process for AG can cause acidi-

Table 1. Moisture, cooking loss (\%), pH, TBARS, and sulfhydryl contents of ready-to eat pork patties with added fresh and aged garlic

\begin{tabular}{|c|c|c|c|c|c|c|}
\hline Items & & Moisture (\%) & $\mathrm{pH}$ & Cooking loss (\%) & TBARS $^{1)}$ & Sulfhydryl ${ }^{2)}$ \\
\hline \multicolumn{7}{|l|}{ Treatment } \\
\hline Control' & & 46.57 & $6.39^{b}$ & $20.66^{b}$ & 1.92 & 6.68 \\
\hline $\mathrm{T} 2^{3)}$ & & 47.32 & $6.32^{c}$ & $21.87^{\mathrm{ab}}$ & 1.2 & 8.15 \\
\hline $\mathrm{T}^{3)}$ & & 48.06 & $6.23^{d}$ & $21.44^{b}$ & 0.86 & 8.45 \\
\hline $\mathrm{T} 4^{3)}$ & & 46.49 & $6.09^{e}$ & $22.32^{\mathrm{a}}$ & 0.52 & 9.98 \\
\hline p-value & & 0.385 & $<0.001$ & $<0.05$ & $<0.001$ & $<0.001$ \\
\hline \multicolumn{7}{|l|}{ Post-treatment } \\
\hline Cooked & & 50.66 & 6.33 & 27.37 & 1.03 & 9.15 \\
\hline Reheated & & 43.73 & 6.24 & 15.88 & 1.37 & 7.24 \\
\hline SEM & & 0.411 & 0.004 & 0.25 & 0.067 & 0.245 \\
\hline p-value & & $<0.001$ & $<0.001$ & $<0.001$ & $<0.001$ & $<0.001$ \\
\hline \multirow[t]{2}{*}{$\mathrm{T} 1$} & $\times$ Cooked & 50.33 & 6.43 & 27.43 & 1.31 & 8.81 \\
\hline & $\times$ Reheated & 44.76 & 6.40 & 16.26 & 1.68 & 6.60 \\
\hline \multirow[t]{2}{*}{$\mathrm{T} 2$} & $\times$ Cooked & 50.79 & 6.38 & 27.46 & 1.15 & 9.32 \\
\hline & $\times$ Reheated & 43.85 & 6.26 & 16.28 & 1.25 & 6.98 \\
\hline \multirow[t]{2}{*}{$\mathrm{T} 3$} & $\times$ Cooked & 51.53 & 6.28 & 27.29 & 0.81 & 9.86 \\
\hline & $\times$ Reheated & 44.60 & 6.17 & 15.59 & 0.91 & 7.04 \\
\hline \multirow[t]{2}{*}{ T4 } & $\times$ Cooked & 50.16 & 6.21 & 28.97 & 0.41 & 10.01 \\
\hline & $\times$ Reheated & 42.82 & 5.96 & 15.66 & 0.64 & 9.95 \\
\hline SEM & & 0.920 & 0.008 & 0.542 & 0.149 & 0.549 \\
\hline$p$-value & & 0.792 & $<0.001$ & 0.069 & 0.062 & 0.126 \\
\hline
\end{tabular}

SEM, standard error of means.

1) Malondialdehyde mg/kg meat. ${ }^{2)} \mathrm{nM} / \mathrm{mg}$ protein.

${ }^{3)}$ Control, pork patties without fresh or aged garlic powder; $\mathrm{T} 1,1 \%$ fresh garlic ( $\left.w / w\right) ; T 2, T 3$, and $\mathrm{T} 4,0.5 \%, 1 \%$, and $2 \%$ aged garlic (w/w).

${ }^{a \cdot e}$ Means within a column followed by different superscripts are significantly different $(p<0.05)$. 
fication [5].

Results of cooking loss of pork patties with added FG/AG powder after roasting and reheating are shown in Table 1. Cooking loss of T4 was significantly higher than that of the control group ( $\mathrm{p}<0.05$ ), whereas cooking loss of $\mathrm{T} 1, \mathrm{~T} 2$, or T3 did not show significant difference from that of the control group ( $p>0.05$ ). According to El-Magoli et al [23], waterholding and fat binding abilities of additive are main factors reducing the cooking loss of meat product. This indicates that water and fat binding capacities of AG powder might be insignificant.

\section{Color}

Results of color (lightness, redness, and yellowness) measurement of fresh pork patties with added FG/AG powder are shown in Table 2. A pre- and post-treatment interaction was observed $(\mathrm{p}<0.001)$ for $\mathrm{L}^{*}$ (lightness), $\mathrm{a}^{*}$ (redness), and $\mathrm{b}^{*}$ (yellowness). Lightness of fresh pork patties was not affected by the addition of $1 \%$ FG powder (T1). However, the lightness was reduced linearly with increasing level of AGP added at post-treatment $(\mathrm{p}<0.001)$. In terms of raw patties, redness value of $\mathrm{T} 1, \mathrm{~T} 2, \mathrm{~T} 3$, or $\mathrm{T} 4$ was significantly lower than that of the control group. However, redness values of T1, T2, T3, and $\mathrm{T} 4$ at post-treatment increased linearly with increasing level of AGP. In addition, the redness of the control group was decreased at post-treatment. These results indicated that the addition of AGP could reduce lightness but increase redness in cooked food with added AGP. This could be due to activation of Maillard reaction accompanied by increased contents of total sugar and amino acids in AG [5,10]. Yellowness was increased linearly with increasing level of AG compared to that of the control group $(\mathrm{p}<0.001)$. Regarding the interaction effect of $L^{*}, L^{*}$ reduction of T4 (from 35.63 to 32.50 ) was less affected than that of other groups after reheating. Moreover, $\mathrm{b}^{\star}$ reduction of T4 (from 21.52 to 16.82) was more affected than that of other groups after the reheating process. Similarly, Shin et al [9] have reported that $b^{*}$ value of sausage with added black garlic extracts is higher than sausage without addition of black garlic extracts.

\section{Brown intensity}

The effect of addition of FG or AG on the BI of fresh, cooked, and reheated pork patties is shown in Figure 2. The BI was increased with increasing level of $A G(p<0.001)$. It gradually increased throughout the cooking procedure $(\mathrm{p}<0.001)$. The $\mathrm{BI}$ at $420 \mathrm{~nm}$ of garlic has been considered as Maillard reaction [24], particularly from the point of view of non-enzymatic browning as shown in Figure 1. An increase in Maillard reaction of AGP during heating has been reported (6), showing that $\mathrm{BI}$ and sulfur compounds of garlic are increased by ageing time and heating process. Yoo et al [25] have reported that $\mathrm{BI}$ of roasted sesame is positively correlated with its antioxi-
Table 2. Color of fresh and ready-to eat pork patties with added fresh and aged garlic

\begin{tabular}{|c|c|c|c|c|}
\hline \multicolumn{2}{|l|}{ Items } & $\mathrm{L}^{*}$ & $a^{*}$ & $b^{*}$ \\
\hline \multicolumn{5}{|l|}{ Treatment } \\
\hline \multicolumn{2}{|l|}{ Control1) } & $52.29^{\mathrm{a}}$ & $7.71^{d}$ & $15.91^{d}$ \\
\hline \multicolumn{2}{|l|}{$\mathrm{T} 1^{1)}$} & $49.44^{b}$ & $7.71^{d}$ & $19.45^{c}$ \\
\hline \multicolumn{2}{|l|}{$T 2^{1)}$} & $45.64^{c}$ & $8.31^{c}$ & $20.07^{b}$ \\
\hline \multicolumn{2}{|l|}{$T 3^{1)}$} & $42.50^{d}$ & $9.16^{b}$ & $21.27^{\mathrm{a}}$ \\
\hline \multicolumn{2}{|l|}{$\mathrm{T} 4^{1)}$} & $37.76^{e}$ & $9.68^{\mathrm{a}}$ & $19.44^{b}$ \\
\hline \multicolumn{2}{|l|}{ SEM } & 0.22 & 0.09 & 0.13 \\
\hline \multicolumn{2}{|c|}{ p-value } & $<0.001$ & $<0.001$ & $<0.001$ \\
\hline \multicolumn{5}{|c|}{ Post-treatment } \\
\hline \multicolumn{2}{|c|}{ Fresh } & $52.41^{\mathrm{a}}$ & $8.97^{\mathrm{a}}$ & $16.17^{c}$ \\
\hline \multicolumn{2}{|l|}{ Cooked } & $44.80^{b}$ & $8.32^{b}$ & $21.86^{\mathrm{a}}$ \\
\hline \multicolumn{2}{|c|}{ Reheated } & $39.34^{c}$ & $8.24^{b}$ & $19.65^{b}$ \\
\hline \multicolumn{2}{|c|}{ SEM } & 0.15 & 0.06 & 0.09 \\
\hline \multicolumn{2}{|c|}{ p-value } & $<0.001$ & $<0.001$ & $<0.001$ \\
\hline \multicolumn{5}{|c|}{ Treatment $\times$ post-treatment } \\
\hline \multirow[t]{3}{*}{ Control } & $\times$ Fresh & 58.69 & 11.31 & 11.42 \\
\hline & $\times$ Cooked & 53.05 & 5.78 & 18.44 \\
\hline & $\times$ Reheated & 45.10 & 6.02 & 17.87 \\
\hline \multirow[t]{3}{*}{ T1 } & $\times$ Fresh & 57.76 & 8.41 & 13.63 \\
\hline & $\times$ Cooked & 48.02 & 7.51 & 23.15 \\
\hline & $\times$ Reheated & 42.51 & 7.20 & 21.56 \\
\hline \multirow[t]{3}{*}{$\mathrm{T} 2$} & $\times$ Fresh & 51.75 & 8.20 & 16.51 \\
\hline & $\times$ Cooked & 45.76 & 8.36 & 22.93 \\
\hline & $\times$ Reheated & 39.40 & 8.35 & 20.78 \\
\hline \multirow[t]{3}{*}{ T3 } & $\times$ Fresh & 48.72 & 8.22 & 19.28 \\
\hline & $\times$ Cooked & 41.56 & 9.61 & 23.26 \\
\hline & $\times$ Reheated & 37.20 & 9.63 & 21.25 \\
\hline \multirow[t]{3}{*}{ T4 } & $\times$ Fresh & 45.14 & 8.69 & 19.99 \\
\hline & $\times$ Cooked & 35.63 & 10.34 & 21.52 \\
\hline & $\times$ Reheated & 32.50 & 10.00 & 16.81 \\
\hline \multicolumn{2}{|l|}{ SEM } & 0.39 & 0.16 & 0.22 \\
\hline \multicolumn{2}{|l|}{ p-value } & $<0.001$ & $<0.001$ & $<0.001$ \\
\hline
\end{tabular}

SEM, standard error of means.

${ }^{1)}$ Control, pork patties without fresh or aged garlic powder; $T 1,1 \%$ fresh garlic (w/ $\mathrm{w}) ; \mathrm{T} 2, \mathrm{~T} 3$, and $\mathrm{T} 4,0.5 \%, 1 \%$, and $2 \%$ aged garlic (w/w).

a-e Means within a column followed by different superscripts are significantly different $(p<0.05)$.

dant activity. In addition, pre-treatment and post-treatment had significant effects on BI $(\mathrm{p}<0.001)$ since the increase of $\mathrm{BI}$ with increasing level of AG was more affected by posttreatments.

\section{2-Thiobarbituric acid reactive substances}

The TBARS of RTE pork patties with added fresh/AGP did not have interaction effect ( $p>0.05$, Table 1$)$. The TBARS in RTE pork patties was reduced with increasing level of AGP (Control, 1.92; T1, 1.49; T2, 1.20; T3, 0.86; and T4, $0.52 \mathrm{MDA}$ $\mathrm{mg} / \mathrm{kg}$ meat, respectively). The TBARS was increased from 1.03 to $1.37 \mathrm{MDA} \mathrm{mg} / \mathrm{kg}$ meat after the reheating process ( $\mathrm{p}<$ 0.001). Despite the addition of the same concentration (T1, 1\% FG and T3, 1\% AG), T3 inhibited lipid oxidation more 

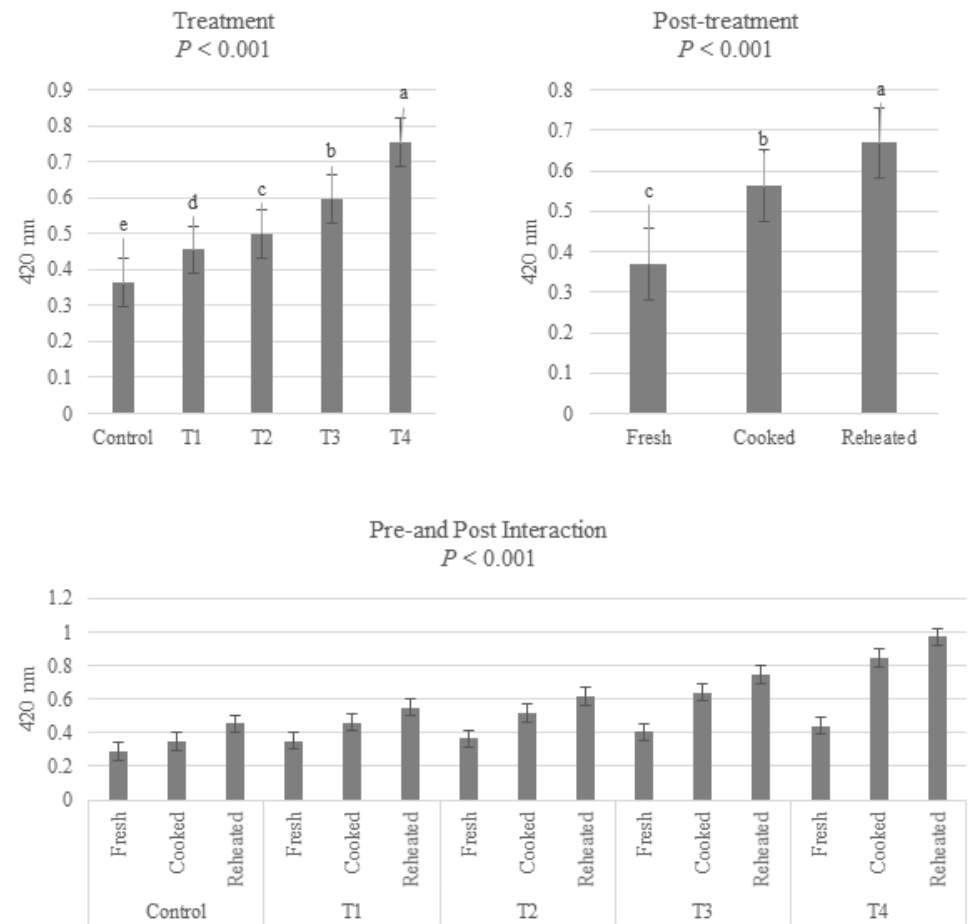

Figure 2. Brown intensity of fresh, cooked and reheated pork patties added fresh/aged garlic powder. Control, pork patties without fresh or aged garlic powder; $T 1,1 \%$ fresh garlic (w/w), T2, T3, and T4, 0.5\%, 1\%, and 2\% aged garlic (w/w).

efficiently than T1. Tarladgis et al [20] have found that the perception of rancidity flavor is related to TBARS (from 0.5 to 1.0 in pork). The effect of the addition of AGP on inhibition of lipid oxidation was verified at both process (cooking and storing/reheating). Antioxidant effect of aged black garlic has been reported in previous studies [8,26]. In particular, MRPs of AG in the reheated samples could be generated during the heating process, resulting in the inhibition of lipid oxidation $[19,25]$. Garlic has stable antioxidant ability after boiling or frying treatment, although its antioxidant ability is lower than FG [27]. In addition, the antioxidant ability of AG increased with increasing heat temperature (from $40^{\circ} \mathrm{C}$ to $85^{\circ} \mathrm{C}$ ) during manufacturing [6].

\section{Sulfhydryl content}

Sulfhydryl contents of RTE pork patties with added FG/AG powder and post-treatment are shown in Table 1. Sulfhydryl content did not show an interaction effect between preand post-treatments ( $\mathrm{p}>0.05)$. Sulfhydryl content in T3 or T4 (8.45 and $9.98 \mathrm{mM} / \mathrm{kg}$ protein, respectively) was considerably higher than that of the control group $(6.68 \mathrm{mM} / \mathrm{kg}$ protein, $\mathrm{p}<0.001)$. However, sulfhydryl content of the control group did not differ from that of T1 or T2 ( $>>0.05)$. Sulfhydryl content was decreased from 9.15 to $7.24 \mathrm{mM} / \mathrm{kg}$ protein after reheating regardless of pre-treatment. Botsoglou et al [28] have demonstrated that natural antioxidant extracts can inhibit the reduction of sulfhydryl contents of cooked patties during refrigerated storage. These results indicated that the addition of $1.0 \%$ to $2.0 \% \mathrm{AG}$ powder inhibited the reduction of sulfhydryl contents in cooked and reheated pork patties compared to non-additives or addition of FG addition at the same concentration. According to Kim et al [29], AG contains higher contents of S-allyl-L-cysteine and diallyldisulfide ( $522.51 \pm 1.19$ and $8.71 \pm 0.45 \mu \mathrm{g} / \mathrm{g}$ sample, respectively) compared to FG $(245.35 \pm 1.35$ and $0.275 \pm 0.15 \mu \mathrm{g} / \mathrm{g}$ sample, respectively). The inhibition of the reduction of sulfhydryl content in FG and AG during the processing could be related to their sulfur-containing antioxidants such as allyl cysteine and allyl disulfide [1].

\section{Texture characteristics}

Texture profiles of cooked/reheated pork patties with added FG/AG powder are shown in Table 3. Pork patties with added AGP showed higher values for gumminess, hardness, and chewiness than those from the control group $(\mathrm{p}<0.05)$. The springiness and cohesiveness did not differ among treatment groups ( $p>0.05$ ). Reheating process significantly increased gumminess, hardness, and chewiness but decreased the springiness. Similar changes in texture profiles (reduction of springiness but increases of gumminess, hardness, and chewiness) by reheating process have been reported for chicken patties with added lotus leaf powder after storage in a refrigerator [30]. In addition, pre- and post- treatment interaction effect of gumminess, hardness, and chewiness occurred ( $\mathrm{p}<$ 
Table 3. Texture profiles of ready-to eat pork patties with added fresh and aged garlic

\begin{tabular}{|c|c|c|c|c|c|c|}
\hline Items & & Springiness (mm) & Gumminess (kg) & Cohesiveness & Hardness (kg) & Chewiness $(\mathrm{kg})$ \\
\hline \multicolumn{7}{|l|}{ Treatment } \\
\hline Control1) & & 0.83 & $3.13^{c}$ & 0.48 & $6.52^{d}$ & $2.58^{b}$ \\
\hline $\mathrm{T} 2^{1)}$ & & 0.83 & $3.31^{\mathrm{bc}}$ & 0.48 & $6.85^{\mathrm{bc}}$ & $2.76^{\mathrm{ab}}$ \\
\hline$T 3^{1)}$ & & 0.83 & $3.49^{b}$ & 0.49 & $7.32^{\mathrm{ab}}$ & $2.89^{\mathrm{a}}$ \\
\hline $\mathrm{T} 4^{1)}$ & & 0.82 & $4.02^{\mathrm{a}}$ & 0.47 & $8.04^{\mathrm{a}}$ & $3.13^{\mathrm{a}}$ \\
\hline \multicolumn{7}{|l|}{ Post-treatment } \\
\hline Cooked & & 0.841 & 2.80 & 0.49 & 5.50 & 2.29 \\
\hline Reheated & & 0.815 & 3.76 & 0.47 & 8.09 & 3.07 \\
\hline SEM & & 0.004 & 0.070 & 0.007 & 0.478 & 0.062 \\
\hline p-value & & $<0.001$ & $<0.001$ & 0.006 & $<0.001$ & $<0.001$ \\
\hline \multirow[t]{2}{*}{$\mathrm{T} 1$} & $\times$ Cooked & 0.84 & 2.18 & 0.48 & 4.34 & 1.84 \\
\hline & $\times$ Reheated & 0.81 & 2.75 & 0.45 & 6.15 & 2.23 \\
\hline \multirow[t]{2}{*}{$\mathrm{T} 2$} & $\times$ Cooked & 0.85 & 3.04 & 0.50 & 6.12 & 2.57 \\
\hline & $\times$ Reheated & 0.82 & 3.58 & 0.46 & 7.58 & 2.94 \\
\hline \multirow[t]{2}{*}{ T3 } & $\times$ Cooked & 0.4 & 3.04 & 0.50 & 6.06 & 2.56 \\
\hline & $\times$ Reheated & 0.82 & 3.94 & 0.47 & 8.58 & 3.22 \\
\hline \multirow[t]{2}{*}{ T4 } & $\times$ Cooked & 0.84 & 3.25 & 0.48 & 5.89 & 2.36 \\
\hline & $\times$ Reheated & 0.81 & 4.80 & 0.47 & 10.20 & 3.91 \\
\hline SEM & & 0.008 & 0.158 & 0.015 & 0.330 & 0.140 \\
\hline$p$-value & & 0.940 & $<0.05$ & 0.857 & $<0.001$ & $<0.001$ \\
\hline
\end{tabular}

0.001) since patties with the highest concentration of AGP (T4) was more affected by the post-treatment compared to control or T1 group. Such changes in texture profiles indicate that polymerization of sulfhydryl-disulfide interchange reaction might have induced protein aggregation by heating due to plentiful thiol groups in AG [29]. This is consistent with results of Andic et al [31] showing that beef patties with added whey powder contain plentiful thiol groups, showing increased hardness and chewiness, in agreement with Ulu [32].

\section{Sensory characteristics}

The effect of fresh/pork addition on texture and juiciness of pork patties results was found to be insignificant (Table 4). However, significant inclining trend score was found in color, flavor, taste, and overall preference of pork patties with increasing levels of AGP $(p<0.05)$. Significant effects of post-treatment on texture and overall preference were observed. The effect of pre-and post-treatment interaction on sensory characteristics was insignificant $(\mathrm{p}>0.05)$.

\section{CONCLUSION}

The AG added at concentrations of $0.5 \%, 1.0 \%$, and $2 \%$ affected physicochemical, texture, and sensory characteristics as well as lipid/protein oxidation of RTE pork patties. In terms of oxidative stability, AG at concentration of 1.0 and $2.0 \mathrm{~g} / 100 \mathrm{~g}$ patties showed antioxidant effect on lipid and protein oxidation. In addition, color of patties with added AG at $2.0 \mathrm{~g} / 100 \mathrm{~g}$ might be acceptable because of Maillard reaction. Although significant difference in flavor, taste, or overall acceptability among patties with either added FG or AG was not observed, however, they showed increasing tendencies with an increasing level of AG. However, high concentrations (1.0 and $2.0 \mathrm{~g} /$ $100 \mathrm{~g}$ patties) of AG showed negative effects on cooking loss and texture characteristics. Therefore, addition of AG to meat products might be able to extend their shelf-life and improve their sensory characteristics. However, further studies are needed to understand the relationship between AG and Maillard reaction in meat products as well as functionalities of MRPs from AG. 
Table 4. Sensory evaluation of ready-to eat pork patties with added fresh and aged garlic

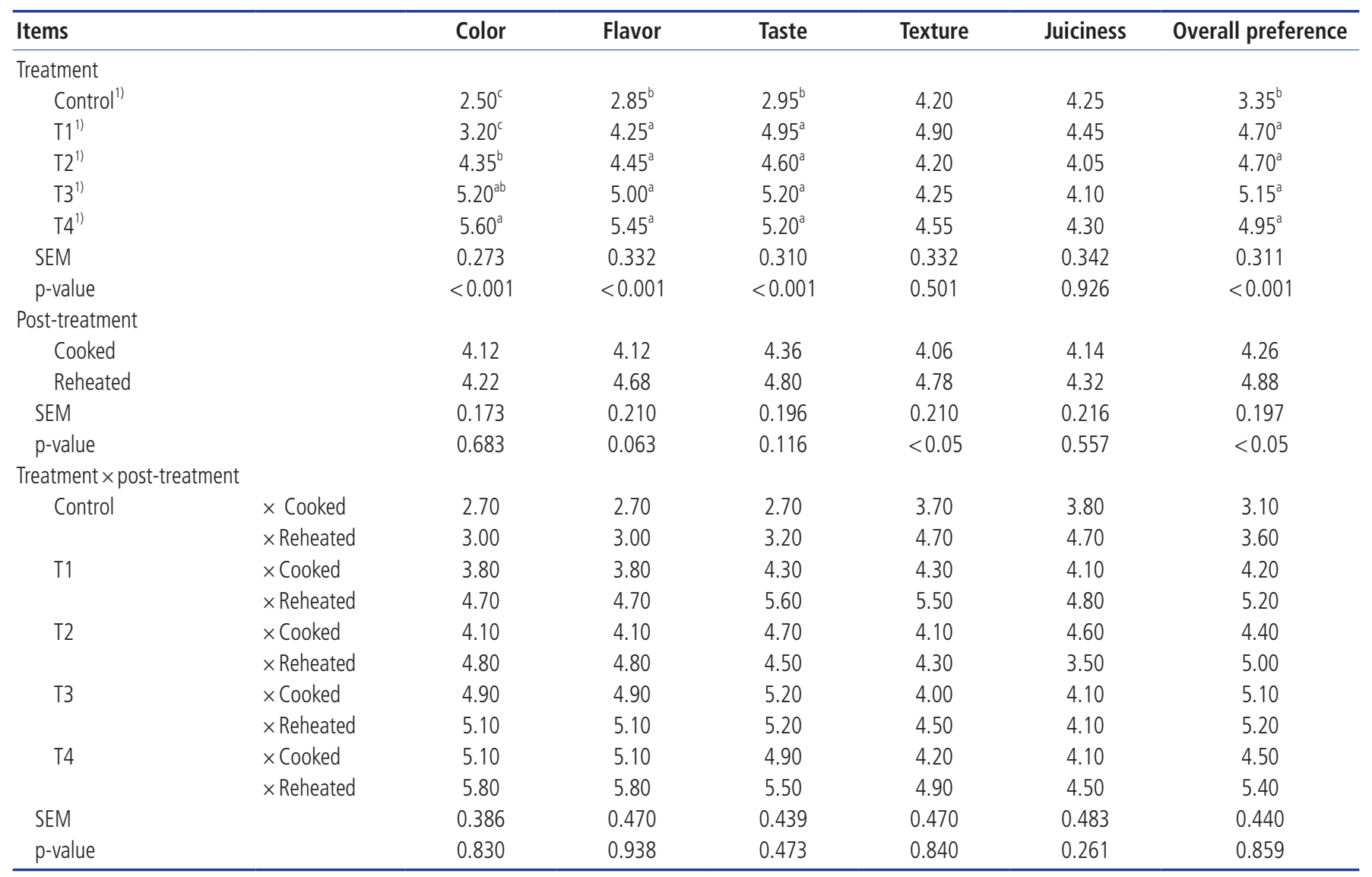

SEM, standard error of means.

${ }^{1)}$ Control, pork patties without fresh or aged garlic powder; $\mathrm{T} 1,1 \%$ fresh garlic ( $\left.\mathrm{w} / \mathrm{w}\right) ; \mathrm{T} 2, \mathrm{~T} 3$, and $\mathrm{T} 4,0.5 \%, 1 \%$, and $2 \%$ aged garlic (w/W).

${ }^{a \cdot e}$ Means within a column followed by different superscripts are significantly different $(p<0.05)$.

\section{CONFLICT OF INTEREST}

We certify that there is no conflict of interest with any financial organization regarding the material discussed in the manuscript.

\section{ACKNOWLEDGMENTS}

This research was supported by the Technology Commercialization Support Program, Small \& Medium Business Administration, Republic of Korea.

\section{REFERENCES}

1. Chung LY. The antioxidant properties of garlic compounds: allyl cysteine, alliin, allicin, and allyl disulfide. J Med Food 2006;9:205-13. https://doi.org/10.1089/jmf.2006.9.205

2. Sallam KhI, Ishioroshi M, Samejima K. Antioxidant and antimicrobial effects of garlic in chicken sausage. LWT 2004;37: 849-55. https://doi.org/10.1016/j.lwt.2004.04.001

3. Mottram DS. Flavour formation in meat and meat products: a review. Food Chem 1998;62:415-24. https://doi.org/10.1016/ S0308-8146(98)00076-4

4. Wakamatsu J, Stark TD, Hofmann T. Taste-active Maillard reaction products in roasted garlic (Allium sativum). J Agric Food Chem 2016;64:5845-54. https://dx.doi.org/10.1021/acs. jafc.6b02396

5. Shin JH, Choi DJ, Lee SJ, Cha JY, Kim JG, Sung NJ. Changes of physicochemical components and antioxidant activity of garlic during its processing. J Life Sci 2008;18:1123-31. https:// doi.org/10.5352/JLS.2008.18.8.1123

6. Bae SE, Cho SY, Won YD, Lee SH, Park HJ. Changes in S-allyl cysteine contents and physicochemical properties of black garlic during heat treatment. LWT - Food Sci Thecnol 2014; 55:397-402. https://doi.org/10.1016/j.lwt.2013.05.006

7. Jung YM, Lee SH, Lee DS, et al. Fermented garlic protects diabetic, obese mice when fed a high-fat diet by antioxidant effects. Nutr Res 2011;31:387-96. https://doi.org/10.1016/j. nutres.2011.04.005

8. Kim JH, Nam SH, Rico CW, Kang MY. A comparative study on the antioxidative and anti-allergic activities of fresh and aged black garlic extracts. Int J Food Sci Technol 2012;47:1176- 
82. https://doi.org/10.1111/j.1365-2621.2012.02957.x

9. Shin JH, Kang MJ, Kim RJ, Sung NJ. The quality characteristics of sausage with added black garlic extracts. Korean J Food Cook Sci 2011;27:701-11. https://doi.org/10.9724/kfcs.2011. 27.6.701

10. Lee J, Seong Y, Jeong B, Yoon S, Lee I, Jeong Y. Quality characteristics of sponge cake with black garlic powder added. J Korean Soc Food Sci Nutr 2009;38:1222-8. https://doi.org/10. 3746/jkfn.2009.38.9.1222

11. Monteiro CA, Levy RB, Claro RM, de Castro IRR, Cannon G. Increasing consumption of ultra-processed foods and likely impact on human health: evidence from Brazil. Public Health Nutr 2010;14:5-13. https://doi.org/10.1017/S1368980010003241

12. Johnston JE, Sepe HA, Miano CL, Brannan RG, Alderton AL. Honey inhibits lipid oxidation in ready-to-eat ground beef patties. Meat Sci 2005;70:627-31. https://doi.org/10.1016/j. meatsci.2005.02.011

13. Akcan T, Estevez M, Rico S, Ventana S, Morcuende D. Hawberry (Crataegus monogyna Jaqc.) extracts inhibit lipid oxidation and improve consumer liking of ready-to-eat (RTE) pork patties. J Food Sci Technol 2017;54:1248-55. https://doi.org/ 10.1007/s13197-017-2578-8

14. Ferreira VCS, Morcuende D, Hernandez-Lopez SH, Madruga MS, Silva FAP, Estevez M. Antioxidant extracts from Acorns (Quercus ilex L.) effectively protect ready-to-eat (RTE) chicken patties irrespective of packaging atmosphere. J Food Sci 2017; 82:622-31. https://doi.org/10.1111/1750-3841.13640

15. Clark EM, Mahoney AW, Carpenter CE. Heme and total iron in ready-to-eat chicken. J Agric Food Chem 1997;45:124-6. https://doi.org/10.1021/jf960054l

16. Falowo AB, Fayemi PO, Muschenje V. Natural antioxidants against lipid-protein oxidative deterioration in meat and meat products: a review. Food Res Int 2014;64:171-81. https://doi. org/10.1016/j.foodres.2014.06.022

17. Berry BW, Bigner-George ME. Factors affecting color properties of beef patties cooked on an outdoor gas grill. J Muscle Foods 2000;11:213-26. https://doi.org/10.1111/j.1745-4573.2000. tb00426.x

18. AOAC. Official methods of analysis. 17th ed. Gaithersburg, MD, USA: AOAC International; 2002.

19. Smith JS, Alfawaz M. Antioxidative activity of Maillard reaction products in cooked ground beef, sensory and TBA values. J Food Sci 1995;60:234-6. https://doi.org/10.1111/j.1365-2621. 1995.tb05644.x

20. Tarladgis BG, Watts BM, Younathan MT, Dugan L. A distillation method for the quantitative determination of malonaldehyde in rancid foods. J Am Oil Chem Soc 1960;37:44-8. https:// doi.org/10.1007/BF02630824
21. Jongberg S, Torngren MA, Gunvig A, Skibsted LH, Lund MN. Effect of green tea or rosemary extract on protein oxidation in Bologna type sausages prepared from oxidatively stressed pork. Meat Sci 2013;93:538-46. https://doi.org/10.1016/j.meatsci. 2012.11.005

22. Bourne MC. Texture profile analysis. Food Tech 1978;32:626.

23. El-Magoli SB, Laroia S, Hansen PTM. Flavour and texture characteristics of low fat ground beef patties formulated with whey protein concentrate. Meat Sci 1996;42:179-93. https:// doi.org/10.1016/0309-1740(95)00032-1

24. Kang OJ. Evaluation of Melanoidins formed from black garlic after different thermal processing steps. Prev Nutr Food Sci 2016;21:398-405. https://dx.doi.org/10.3746/pnf.2016.21.4.398

25. Yoo MI, Kim HW, Kim KH, Kang MH. Antioxidant effect of brown substances separated from defatted roasted sesame dregs. Food Sci Biotechnol 2004;13:274-8.

26. Jang HJ, Lee HJ, Yoon DK, Ji DS, Kim JH, Lee CH. Antioxidant and antimicrobial activities of fresh garlic and aged garlic byproducts extracted with different solvents. Food Sci Biotechnol 2018;27:219-25. https://doi.org/10.1007/s10068-017-0246-4

27. de Queiroz YS, Antunes PB, Vicente SJV, et al. Bioactive compounds, in vitro antioxidant capacity and Maillard reaction products of raw, boiled and fried garlic (Allium sativum L.). Int J Food Sci Technol 2014;49:1308-14. https://doi.org/10. 1111/ijfs. 12428

28. Botsoglou E, Govaris A, Ambrosiadis L, Fletouris D, Papageorgiou G. Effect of olive leaf (Olea Europea L.) extracts on protein and lipid oxidation in cooked pork meat patties enriched with n-3 fatty acids. J Sci Food Agric 2014;94:227-34. https://doi. org/10.1002/jsfa.6236

29. Kim MS, Kim MJ, Bang WS, Kim KS, Park SS. Determination of S-Allyl-L-cysteine, Diallyl disulfide, and total amino acids of black garlic after spontaneous short-term fermentation. J Korean Soc Food Sci Nutr 2012;41:661-5. http://dx.doi.org/ 10.3746/jkfn.2012.41.5.661

30. Choi YS, Choi JH, Kim HY, et al. Effect of lotus (Nelumbo nucifera) leaf powder on the quality characteristics of chicken patties in refrigerated storage. Korean J Food Sci Anim Res 2011; 31:9-18. https://doi.org/10.5851/kosfa.2011.31.1.009

31. Andic S, Zorba O, Tuncturk Y. Effect of whey powder, skim milk powder and their combination on yield and textural properties of meat patties. Int J Agric Biol 2010;12:871-6.

32. Ulu H. Effect of wheat flour, whey protein concentration and soya protein isolate on oxidative processes and textural properties of cooked meatballs. Food Chem 2004;87:523-9. https:// doi.org/10.1016/j.foodchem.2004.01.002 